\title{
Recognizing and Realizing the Value of Customer-Focused Property Management
}

\begin{tabular}{|r|l|}
\hline Journal: & Property Management \\
\hline Manuscript ID & PM-04-2020-0029.R1 \\
\hline Manuscript Type: & Research Paper \\
\hline Keywords: & $\begin{array}{l}\text { Property management, Real estate operations, Customer service, } \\
\text { Customer satisfaction, Value creation }\end{array}$ \\
\hline \multicolumn{2}{|l}{} \\
\hline
\end{tabular}

\section{SCHOLARONE \\ Manuscripts}




\section{Recognizing and Realizing the Value of Customer-Focused Property Management}

\section{Introduction}

Property managers who treat tenants as valued customers put the real estate investors they represent in a better position to achieve their financial goals (Sanderson, 2019). Yet, there is some evidence that many property managers and property management firms have difficulty differentiating themselves from their peers based on the quality of customer service they provide (Read et al., 2016; Read and Carswell, 2019). This is arguably a product of a poor understanding of what customer-focused property management entails and the mechanisms through which it can affect real estate returns (Sanderson and Devaney, 2017).

This literature review synthesizes the results of research conducted around the world to examine the value proposition of customer-focused property management. It assumes a model of property management in which property managers are paid by landowners from whom companies or individuals rent space. Property managers may be employees of landlords or they may be agents retained on a fee basis, but in either case, they are anticipated to be responsible for administering leases, overseeing the maintenance of buildings, and responding to tenant concerns. Thus, they are expected to play a key role in providing customer service and ensuring tenant satisfaction.

Three themes emerge from the literature. First, property managers can add significant value to real estate portfolios by delivering high quality customer service to tenants. Second, emerging trends in the real estate industry are creating new opportunities for property managers to participate in the value creation process. Third, there are a number of steps property managers and property management firms can take to leverage customer service systematically, to the benefit of the real estate investors they represent. These themes are 
discussed in the sections that follow, to highlight the financial benefits of customer-focused property management and to explain how these benefits can be realized in practice.

\section{The Value Proposition of Customer-Focused Property Management}

Property management has evolved over the last century into an occupation heavily focused on maximizing the value of income-producing real estate assets (Goss and Campbell, 2008; Klink, 2019). As a result, individuals working in the field today are responsible for a myriad of tasks that were until recently outside the scope of the typical property manager's duties (Read and Carswell, 2019). One such task is developing and implementing procedures to deliver excellent customer service (Palm, 2011). Customer service procedures contribute to the value maximization process by helping real estate investors attract tenants, retain tenants, and achieve top of market rents (Sanderson, 2019).

Customer-focused property management makes sense intuitively, so it is surprising that only recently has it become a priority for a large number of real estate investors. In fact, there is some evidence that adversarial relationships between landlords and tenants were quite common up until the late $20^{\text {th }}$ century, with the former quickly turning to legal processes to resolve disputes with the latter (Sayce et al., 2009). Such an approach fails to recognize that tenants are mobile and can take their business elsewhere in the event they are dissatisfied with the service they receive (Edington, 1997).

High quality customer service undoubtedly means different things in different sectors of the real estate industry, but there are at least a few common elements upon which many scholars agree. Property managers are expected to act in a professional manner and ensure properties are in good working order (Chin and Poh, 1999), while demonstrating responsiveness to tenants' needs and accountability when things go wrong (Wilson et al., 
2001). They are also expected to be caring, loyal, trustworthy, and easy to contact, in addition to providing good value-for-money (Sanderson, 2019).

Satisfying these expectations is important because it may dictate whether tenants stay or go when their lease terms expire (Edington, 1997). Two research projects clearly illustrate the point. In a study of approximately 4,400 office, industrial, and retail tenants in the United Kingdom, Sanderson (2016) found empathy, professionalism, responsiveness, and trustworthiness on the part of property managers are key determinants of tenant satisfaction and of tenants' stated likelihood of renewing their leases. The results are consistent with the work of Kingsley Associates (2004) who found commercial tenants in the United States are more likely to renew their leases when they are satisfied with property management.

The benefits of customer-focused property management do not accrue to commercial real estate alone. Sanderson (2019) found residents' perceptions about property management are indicators of both their likelihood of renewing leases and their willingness to recommend property managers to others. Research using professional certifications as a proxy for property management quality also suggest customer service can positively influence apartment rents (Sirmans and Sirmans, 1992).

There are, additionally, studies that examine the impact of tenant satisfaction on real estate investment returns. Westlund et al. (2005) observed strong correlations between measures of tenant satisfaction and measures of financial performance in the Swedish commercial real estate market after taking a time lag into account. Similarly, Sanderson and Devaney (2017) found a one unit increase in mean tenant satisfaction, as measured on a fivepoint scale, increased annual total returns to commercial real estate investors in the United Kingdom by nearly two percentage points - a gain both practically and statistically significant. The superior financial returns were hypothesized to stem from lower vacancy 
rates, higher lease renewals, and the ability to charge premium rents for delivering an excellent customer experience.

\section{The Growing Importance of Customer-Focused Property Management}

Research quantifying the value proposition of customer-focused property management is admittedly sparse, but the studies that do exist suggest there is a relationship between customer service and the financial performance of income-producing real estate assets that should not be ignored (Li and Monkkonen, 2014; Oyedokun et al., 2014). This might lead one to believe that delivering high quality customer service is a way for property managers and property management firms to differentiate themselves effectively from their peers. However, intense price competition in the market for property management services indicates that this often proves difficult to do (Read et al., 2016). Far too many real estate investors appear to view property management as a commodity rather than a differentiated service capable of adding value to real estate portfolios (Read and Carswell, 2019).

Addressing this misconception is important, not only because it fails to take into account property managers' proven ability to drive revenues, but also because it disregards emerging trends in the real estate industry that are likely to make customer service an even more critical part of property managers' jobs in the future. Figure 1 presents five such trends, which are discussed below.

\section{INSERT FIGURE 1 HERE}

\subsection{Heightened tenant demands}

Scholars and practitioners alike agree that a structural shift has taken place in the real estate industry over the last two decades (Alter, 2008; Bell, 2002; Lindholm, 2008; Palm, 
2016). Both commercial and residential tenants now demand more from their landlords and property managers than they did in the past (Appel-Meulenbroek, 2008; Noor and Pitt, 2009; Sanderson, 2019). Heightened demands can be observed in the amenities tenants seek out, the lease terms they negotiate, and the level of customer service they require from property management teams (Ashuria, 2010; Rasila, 2010; Seetharaman et al., 2017). This is particularly true in well-developed real estate markets around the world, but tenant demands appear to be on the rise in developing markets as well (Ojekalu et al., 2019a; Taylor, 2014).

Heightened tenant demands in the realm of customer service logically manifest themselves in different ways across different real estate product types. For example, retail tenants are increasingly putting pressure on property managers to drive shopper footfall and dwell time (i.e. shopper numbers and the duration of their visit)-through the capital improvement and tenant mix recommendations they make (Chebat et al., 2014; Morgan and Sanderson, 2009); office and industrial tenants are increasingly calling on property managers to help them exploit linkages between real estate and employee productivity (Bortoluzzi et al., 2018; Read and Sanderford, 2017); and residential tenants are increasingly asking property managers to take steps to build community among occupants of multifamily housing (Sanderson, 2019). Across all of these product types, there is also a growing expectation that property managers engage in place-making activities that provide tenants with areas to relax and interact, while also instilling them with a sense of pride in the spaces where they live, work, play, and shop (Thompson, 2008; Wagner and Watch, 2017).

The examples presented by no means capture all of the ways in which the responsibilities of property managers are changing in response to heightened tenant demands. But, they do support the widely held notation that property managers can no longer do their jobs effectively when they devote more attention to buildings than to the people who occupy them (Appel-Meulenbroek, 2008; Palm, 2016; Morgan et al., 2017). In fact, there are those 
who now believe few factors are likely to contribute more to property managers' success in the future than the quality of customer service they provide to tenants and the strength of the relationships they build with them (Lindholm, 2008; Noor and Pitt, 2009; Palm, 2011; 2013; Ojekalu et al., 2019 ; Sanderson, 2016). This is likely to be exacerbated by the repercussions of the Covid-19 pandemic, as many tenants face financial hardship, and many businesses will not survive enforced lockdown measures. In times of over-supply of property, superior property management service has been shown to be of particular importance (Sanderson and Devaney, 2017).

\subsection{Space as a service movement}

One tenant requirement that has put significant pressure on property managers to improve their performance is the demand for flexibility. Long term leases have historically been the norm in developed real estate markets because they provide landlords with greater cash flow stability across economic cycles than short term leases (Bannister, 2008; Crosby et al., 2006; Edington, 1997; Halvitigala et al., 2011). However, this is starting to change. Tenants with bargaining power are increasingly asking for short term leases, or long term leases with break clauses, so they can more quickly adjust their real estate portfolios to their evolving space needs (MSCI and BNP Paribas, 2018). This is likely to be exacerbated in the aftermath of the Covid-19 pandemic, as businesses realise that staff are able to work productively from home, and employees have appreciated the time saved by not having to $\underline{\text { commute to work. Landlords who acquiesce to these demands for greater lease flexibility }}$ directly or indirectly call on their property managers to provide better customer service because tenants can leave in short order in the event that they are unsatisfied (Sanderson and Edwards, 2016). Property managers need to ensure occupiers have a reason to make use of $\underline{\text { their official workplace so that leases are renewed. }}$ 
Companies offering "space as a service" have pushed tenant demands for flexibility even further (Sargent et al., 2018). It is now possible for tenants to procure space by the month, week, day, or even hour depending upon their needs (Poleg, 2020). WeWork and Airbnb are perhaps the best known examples of the space as a service movement, but pop-up stores and on-demand warehouse space are also available in many markets to accommodate retail and industrial tenants in need of extreme flexibility (Ward, 2018). Providers of space as a service have disrupted the real estate industry by forcing traditional landlords to put forth flexible options, many of which are customer service intensive (Morgan et al., 2017).

Space as a service models will undoubtedly change over time in response to market conditions, but it seems unlikely that the real estate industry will ever revert entirely to the inflexible, long-term lease agreements of the past. The main implication for property managers is that they will have to work harder to retain tenants. Their ability to do so may hinge on their commitment to building relationships with tenants and delivering an experience they cannot get elsewhere.

\subsection{Technology-driven market disruptions}

The space as a service movement is but one of many technology-driven market disruptions reshaping the real estate industry in interesting ways (Sanquist, 2013). New technologies are also shifting the amount of demand that exists for various types of real estate and redefining the features that make one property more or less competitive than another. Property managers must remain vigilant in understanding these technological advancements if they hope to serve as effective intermediaries between tenants and landlords.

The rise of e-tailing and the remote worker phenomenon are perfect examples of how technology can impact demand for real estate, and in turn the work of property management professionals (Jones and Livingstone, 2015; Knapp et al., 2019). These technology-driven 
market disruptions have diminished demand for certain types of retail and office space, making it all the more essential for property managers working in these sectors to understand and respond to tenants' needs. This may involve seeking out ways to make retail and office properties more enjoyable places to visit and/or organizing events that offer opportunities for social interactions only available to those shopping or working onsite (Morgan and Sanderson, 2009; Read and Sanderford, 2017; Savills, 2019).

Property managers must additionally understand how technology can make properties more attractive to tenants. Over $\$ 6$ billion in venture capital was invested in the PropTech sector over the last decade (Cushman and Wakefield, 2018). Many start-ups competing in this space offer a range of products and services designed to enhance the tenant experience (Lecamus, 2019). The rate of innovation has been so rapid that technologies recommended only a few years ago now seem passé (Morgan and Sanderson, 2009). Staying on top of these advancements is not easy, but tenants now expect property managers to do so to help them maximize the value of the real estate they occupy and minimize the cost (Harris, 2019; Sanderson and Edwards, 2016). It stands to reason that this dimension of customer-focused property management will only increase in importance in the future.

\subsection{Proliferation of sustainability initiatives}

Some emerging technologies help property managers operate buildings more efficiently (Devine and Yonder, 2017). This is fortunate in light of the proliferation of sustainability initiatives and resource conservation efforts around the world (Feist, 2015; Read and Sanderford, 2018). However, familiarity with "smart" building systems is only one way in which property managers can advance sustainability agendas. Others include maintaining eco-certifications, engaging in eco-benchmarking, and administering green leases (Christensen et al., 2018; Rameezdeen et al., 2019). Property managers who do these 
things well align the interests of tenants interested in reducing real estate costs, increasing employee productivity, and conveying an environmentally-friendly image with those of landlords interested in achieving higher rents, occupancy, property values, and returns (Baird and Dykes, 2012; Eicholtz et al., 2010; Feige et al., 2013; Freybote and Qian, 2017; Furst and McAllister, 2011; Miller et al., 2008; Robinson and McAllister, 2015; McGrath, 2013).

Many real estate investors obtain eco-certifications such as BREEAM or LEED for their buildings to publicize their commitment to sustainability and to satisfy the demands of tenants who wish to do the same (Cole and Valdebenito, 2013; Ferreira et al., 2014; Gabe et al., 2019). They may also commit to satisfying GRESB reporting requirements to signal to the market that they care about environmental preservation (Christensen, 2017). All of these decisions have implications for property managers who are frequently left to establish environmental objectives, monitor and measure their attainment, and take actions to improve performance when necessary (Read and Sanderford, 2018).

Legal rights and obligations related to eco-certifications and eco-benchmarking are frequently established in "green" leases, which property managers are called on to administer (Axom et al., 2012; Collins and Junghans, 2015; Janada et al., 2016; Sayce et al., 2019). This may involve any number of activities including managing onsite recycling programs, overseeing the installation and operation of high efficiency building systems, or promoting alternative modes of transportation (Adnan et al., 2017; Rameezdeen et al., 2017). Green leases may also require good faith efforts on the part of property managers to comply with the terms of nonbinding memoranda of understanding and environmental management plans (Bright and Dixie, 2014). The level of customer service provided by property managers can impact the success of sustainability initiatives due to the complexity of these activities.

\subsection{Threat of regulatory intervention}


It is not just market forces that encourage property managers to become more and more involved in sustainability initiatives; regulatory forces are at play as well. Australia and several countries in the European Union have put laws in place requiring some property owners to comply with environmentally friendly management practices and disclose energy consumption data (Gabe, 2016; Hsu, 2014; Mclean and Jegede, 2014; Thompson, 2015). Similar mandates exist at the municipal level in other countries (Christensen et al., 2018).

There are also instances where regulation of the property management industry extends well beyond matters of sustainability. In the United Kingdom, for example, several steps have been taken to force property managers to treat tenants better, in spite of efforts by organisations such as the British Property Federation to take the initiative in treating tenants as customers in the hope of pre-empting and avoiding such legislation (Morgan, 2013). Regulations have been put in place to improve the quality of the commercial and residential building stock and increase transparency in the assessment of service charges (UK Government, 2002; 2019). The scope of these regulatory interventions compelled the Royal Institute of Chartered Surveyors (RICS) to issue various codes of conduct and guidance notes designed to improve the reputation of the property management industry and the quality of customer service delivered to tenants (RICS, 2009; 2011; 2014, 2016).

Regulatory interventions clearly create additional work for property managers. However, they also create opportunities. Property managers who are committed to treating tenants as valued customers are likely to find it much easier to adhere to regulatory mandates that exist today, as well as those that may come into being in the future.

\section{Best Practices in Customer-Focused Property Management}

The aforementioned trends clearly support the contention that customer service can serve as a source of competitive advantage. Less clear is whether property managers and 
property management firms are well positioned to take advantage. Morgan et al. (2019), among others, posit that the property management industry at large is currently ill equipped to deliver the quality of customer service tenants increasingly expect. Fortunately, there are best practices that can be adopted to address the problem. Ten are presented in Figure 2.

\section{INSERT FIGURE 2 HERE}

\subsection{Build on a strong foundation}

Nearly a quarter-century ago, Edington (1997) put forth a customer service model for the property management industry. It emphasizes the importance of enabling, empowering, and encouraging property managers to use the information at their disposal to assess tenants' needs, respond to them, and measure the extent to which they are being satisfied. The model remains relevant to this day because it suggests customer-focused property management is hard, but not necessarily complex (Sanderson, 2019). Listening to tenants, making them feel special, and treating them the way they want to be treated are still essential to strong customer service platforms (Aaker, 2011; Chasick, 2002; Williford, 2005). Those who fail to embrace these fundamentals stand little chance of winning tenants' favour or differentiating themselves from their peers in positive ways (Blanton et al., 2004; Miller, 2001).

\subsection{Communicate early and often}

Customer-focused property management is made possible by ongoing communication (Poon and Brownlow, 2014). It might occur through formal or informal meetings, one-to-one conversations, telephone calls, or email exchanges, but what is most important is that the channels of communication account for tenants' preferences (Rasila, 2010). Generally speaking, the easier it is for tenants to express their concerns, the better (Sanderson, 2016). Support lines with extended hours and online reporting tools must therefore complement more direct interactions with property management teams (Alter, 2008; Nelson, 2010). 
Failing to maintain these channels of communication exposes property managers, as well as the landlords they represent, to substantial reputational risk because dissatisfied tenants can easily turn to social media to make their voices heard if they feel it is necessary. Such negative voices tend to get amplified more loudly than positive ones (Pinker, 2018; Wade, 2012).

\subsection{View all interactions with tenants as opportunities}

Property managers have the greatest chance of improving the quality of the customer service they provide when they view all interactions with tenants as opportunities to gain information about what adds to or detracts from their satisfaction (Alter, 2008). Customer journey mapping is one way to do this systematically (Morgan et al., 2012). It involves mapping out the events, encounters, and situations tenants are likely to experience over the course of their tenancies and identifying ways to enhance the customer experience at each of these touchpoints (Morgan et al., 2017). The most useful customer journey maps are not overly complex and help property managers collaborate effectively with service partners such as building engineers and maintenance staff (Rosenbaum et al., 2017). The latter feature, referred to in the literature as multidimensionality, ensures customer journey maps recognize that property managers are not the only parties who engage with tenants on a regular basis.

\subsection{Use technology to improve, not replace, human connections}

After constructing customer journey maps, careful consideration must be given to how technology is used at various tenant touchpoints. This is the case because technology adoption involves compromises and trade-offs. For example, programs facilitating online rent payments and maintenance requests are beneficial because they reduce customer effort (Dixon et al., 2013). However, they also reduce the amount of time property managers spend interacting with tenants in the ordinary course of business, thereby potentially making it more 
difficult for the parties to build strong professional relationships that lead to loyalty and advocacy (Sanderson and Edwards, 2016). Whether trade-offs such as this result in a net gain or net loss in tenant satisfaction may depend in part on what property managers do with the time they save by automating routine administrative tasks (Thompson, 2015). If the time savings are devoted to activities that truly require a personal touch, property managers can use technology to improve, not replace, human connections (BOMA, 2018; Lu et al., 2014).

\subsection{Deliver value-for-money in a transparent manner}

An activity that does require a personal touch is making sure tenants understand and appreciate what they are getting for their money. This is important in all situations, but perhaps never more so than when landlords assess service charges on top of rent (Halvitigala et al., 2011). Poorly understood service charges can lead to conflicts with tenants that stand in the way of customer-focused property management. To avoid this, property managers should discuss service options with tenants and make the cost implications known (Morgan and Sanderson, 2009; Morgan et al., 2017). They should also determine what services are actually valued by tenants, seek to build consensus before making any large expenditures, and use bulk buying power whenever possible to bring down costs (Morgan et al., 2012; Sanderson, 2016). Taking these steps increases the likelihood of tenants viewing service charges as fair, transparent, and well-managed (Noor and Pitt, 2009; Noor et al., 2010; Tucker and Pitt, 2010).

\subsection{Recruit and retain property managers who believe in customer service}

To deliver best practice in customer-focused property management, staff with the right attitude and skills must be in place. A talent management framework for the real estate industry devised by Phillips and Roper (2009) indicates that companies must excel in five areas to achieve this goal: attraction, selection, engagement, development, and retention. In 
regards to attraction and selection, a growing number of real estate owners and operators are looking in non-traditional places for talent - turning to individuals with hospitality, retail, and public service backgrounds who have already demonstrated a commitment to customer service that can potentially be transferred to the property management field (Morgan et al., 2019; Read, 2019). They are engaging and developing talent through a combination of inhouse and outsourced training programs with robust customer service components (Morgan et al., 2017). Finally, they are retaining talent by not only championing customer service at the corporate level, but also by formally recognizing it in employee performance evaluations and tying those evaluations to financial compensation (Azasu, 2012; Levy and Lee, 2009).

\subsection{Commit to continual organizational improvement}

Although existing studies highlight some of the ways in which the property management industry is getting better at talent management, one should not interpret this body of work as suggesting talent management is no longer a problem. Meeting human resource needs in this area remains difficult for many firms, which undermines their ability to make customer-focused property management a priority (Dobrian, 2015; Phillips, 2014). There are also firms whiche struggle to provide tenants with high quality customer service because the property managers they are able to attract lack motivation to empathise with their

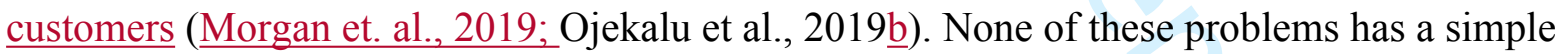
solution, but what separates industry leaders from the pack is their refusal to treat poor customer service as an unavoidable product of market forces (Dobrian, 2017). They commit to continual improvement across all levels of their organizations and embrace customer service as a core value (Hunt, 2017).

\subsection{Empower property managers to take action}


Organizations that commit to customer-focused property management must support that decision by empowering their staff to take action. Responsiveness to tenant requests and a willingness to show flexibility to accommodate tenant requirements are key determinants of tenant satisfaction that cannot be overlooked (Sanderson \& Edwards, 2016). Neither responsiveness nor flexibility are possible unless significant power to make decisions is devolved to property managers (Morgan et al., 2017). Likewise, property managers who are not empowered may find it difficult, if not impossible, to be proactive in taking steps to improve the tenant experience (Read et al., 2016). This is problematic because proactivity on the part of property managers and a willingness to offer innovative ideas are synonymous with customer service in some sectors of the real estate industry (Hwa et al., 2019). For all of these reasons, organizations should give considerable thought to the amount of autonomy and professional discretion they accord property managers if they hope to put them in a position to provide tenants with consistent, high quality customer service (Yip, 2000; Read and Carswell, 2019; Yip, 2000).

\subsection{Carefully consider the structure of third-party property management agreements}

Real estate investors who outsource property management must be particularly mindful of issues of empowerment (Londerville, 2012; Palm, 2018; Thompson, 2015). When contractual agreements fail to strike an appropriate balance between autonomy and control, they provide fee managers with little incentive to be proactive in seeking ways to improve customer service (Read, 2019). In fact, in an effort to mitigate their own contractual risk, third-party property management firms may find it advantageous to forego customer service efforts that are not readily observable by their clients in favour of simply managing to the terms of management agreements. No one wins from such behaviour because it reinforces perceptions that property managers are order-takers, rather than value creators, who must be explicitly told how to satisfy customers' needs (Read and Carswell, 2019). Third-party 
property management firms and real estate investors should openly discuss these threats if they hope to craft contractual agreements that align interests in support of customer-focused property management (Benjamin et al., 2006; Farncombe and Waller, 2005; Palm, 2013).

\subsection{Critically evaluate property management capacity}

Concerns about the structure of third-party property management agreements are part of a larger debate as to whether insourcing or outsourcing property management leads to better customer service outcomes (Palm, 2013; Read et al., 2016). The results are inconclusive but do suggest sophisticated real estate investors have differing perspectives on the topic and see merit in both approaches depending upon context. For example, insourcing property management may provide real estate investors with more control over how customer service programs are implemented, whereas outsourcing may make it easier for real estate investors to hire and fire property managers according to the quality of customer service they deliver (Fink, 2015). Other factors are likely to influence insourcing/outsourcing decisions as well, but regardless of the approach chosen, it is essential for real estate investors to evaluate the capacity of any property managers whose services are retained (Chiang and Perng, 2018). Comprehensive evaluations of managing agents should include some discussion of whether they share a real estate investor's customer service philosophy and whether they have the organizational infrastructure needed to put that philosophy into practice (Read et al., 2017).

\section{Conclusions}

In aggregate, the real estate literature makes a strong case for customer-focused property management. It offers compelling evidence that treating tenants as valued customers can improve the financial performance of income-producing properties and put the real estate investors who own them in a better position to take advantage of emerging market trends. 
Furthermore, it suggests these benefits can be realized by adopting a series of time-tested best practices that keep customer service at the heart of real estate operations.

The challenge for real estate owners and operators lies in putting best practice into action. Nothing in the real estate literature suggests this is an easy task, but academics and practitioners alike tend to agree that value can be derived from doing so. Thus, this manuscript serves as a call to action for real estate investors, property managers, and property management firms who have historically devoted too little thought to customer service.

Notable gaps in the real estate literature also highlight opportunities for future research. First, much more work needs to be done to quantify the impact of property management quality on investment returns across markets and market cycles. Without additional evidence of its value proposition, real estate investors are unlikely to dedicate the resources necessary to make customer-focused property management a priority. Second, the effectiveness of customer service training programs needs to be evaluated. Human resource departments, trade organizations, and universities have all expanded their offerings in this area, but the impact of the training has not yet been rigorously examined. Third, few studies consider how corporate commitments to customer service are communicated to property managers, or conversely, how property managers' expertise in customer service is communicated to corporate executives to inform their decisions. Both issues require consideration to determine how channels of communication can potentially be improved.

\section{References}

Aaker, D.K. (2011). Golden nuggets of customer service: Decrease turnover and build relationships by becoming a customer service guru. Journal of Property Management, $76(6), 33-35$.

Adnan, Y.M., Aman, N.U., Razali, M.N., and Daud, M.N. (2017). The implentation of green 
lease practices for office buildings in Kuala Lumpur, Malaysia. Property Management, 35(3), 306-325.

Alter, S. (2008). Managing properties in a fast paced world; How to make communication and customer service a priority. Journal of Property Management, 73(6), 30-32.

Appel-Meulenbroek, R. (2008), Managing "keep" factors of office tenants to raise satisfaction and loyalty, Property Management, 26(1), 43-55

Ashuria, A. (2010). Valuation of flexible leases for corporate tenants facing uncertainty in their required work space. International Journal of Strategic Property Management, 4(1), 49-72.

Axon, C., Bright, S., Dixon, T., Janda, K., and Kolokotroni, M. (2012). Building communities: Reducing energey use in tenanted commercial property. Building Research and Information, 40(4), 461-472.

Azasu, S. (2012). A survey of reward management practices in the Swedish real estate sector. Property Management, 30(5), 449-464. https://doi.org/10.1108/02637471211273419

Baird, G., \& Dykes, C. (2012). The Potential for the Use of the Occupants' Comments in the Analysis and Prediction of Building Performance. Buildings, 2(4), 33-42. https://doi.org/10.3390/buildings2010033

Bannister, E. (2008). Commercial Leases 2009: A Surveyor's Guide. (Field Fisher Waterhouse, Ed.). Coventry: RICS.

Bell, J. (2002). Service with a style: Property managers are serving up quality customer service to attract and retain tenants. Journal of Property Management, 67(4), 24-28.

Benjamin, J. D., Chinloy, P., \& Hardin, W. G. (2006). Local Presence, Scale and Vertical Integration: Brands as Signals. The Journal of Real Estate Finance and Economics, 
33(4), 389-403.

Blanton, B., Turner, H., and Grossman, K. (2004). NOI tonic: Proactive, integrated service and creative, cost-effective concessions bolster retention and preserve the bottom line in soft multifamily markets. Journal of Property Management, 69(7), 42-44.

BOMA. (2018). Keeping Tenants Happy: The Ultimate Guide to Tenant Retention. BOMA Magazine, 14(6), 42.

Bortoluzzi, B., Carey, D., McArthur, J. J., \& Menassa, C. (2018). Measurement of workplace productivity in the office context: A systematic review and current industry insights. Journal of Corporate Real Estate, 20(4), 281-301.

Bright, S., and Dixie, H. (2014). Evidence of green leases in England and Wales. International Journal of Law and the Built Environment, 6(1/2), 6-20.

Chasick, D.D. (2002). Sweeping changes: The right attitude and proper training add up to great customer service. Journal of Property Management, 67(6), 80.

Chebat, J. C., Michon, R., Haj-Salem, N., \& Oliveira, S. (2014). The effects of mall renovation on shopping values, satisfaction and spending behaviour. Journal of Retailing and Consumer Services, 21(4), 610-618. https://doi.org/10.1016/j.jretconser.2014.04.010

Chiang, T.Y., and Perng, Y.H. (2018). A new model to improve service quality in the property management industry. International Journal of Strategic Property Management, 22(5), 436-446.

Chin, L., \& Poh, L. K. (1999). Implementing quality in property management - The case of Singapore. Property Management, 17(4), 310-320.

Christensen, P. (2017). A post-global financial crisis (GFC) framework for strategic planning, 
assessment, and management decision making for US sustainable commercial real estate. Journal of Property Investment \& Finance, 35(6), 589-618.

Christensen, P.H., Robinson, S.J., and Simons, R.A. (2018). The influence of energy considerations on decision making by institutional real estate owners in the U.S. Renewable and Sustasianble Energy Reviews, 94, 275-284.

Cole, R.J., and Valdebenito, M.J. (2013). The importation of building environmental certification systems: International usages of BREEAM and LEED. Building Research and Information, 41(6), 662-676.

Collins, D., and Junghans, A. (2015). Sustainable facilities management and green leasing: The company strategic approach. Procedia Economics and Finance, 21, 128-136.

Crosby, N., Hughes, C., \& Murdoch, S. (2006). Flexible Property Leasing and the Small Business Tenant. Journal of Property Research, 23(2), 163-188.

Cushman \& Wakefield. (2018). The Occupier Edge 6th Edition.

Devine, A., \& Yonder, E. (2017). Decomposing the Value Effects of Sustainable Real Estate Investment: International Evidence. Retrieved from https://www.ipf.org.uk/resourceLibrary/decomposing-the-value-effects-of-sustainablereal-estate-investment---international-evidence-2017-nick-tyrrell-research-prize.html

Dixon, M., Toman, N., \& DeLisi, R. (2013). The Effortless Experience: Conquering the New Battleground for Customer Loyalty. London: Penguin.

Dobrian, J. (2015). Talent management: What it takes to attract, retain and develop great minds. Journal of Property Management, 80(3), 48-53.

Dobrian, J. (2017). Talent management: Creating and maintaining a brand. Journal of Property Management, 82(4), 12-16. 
Edington, G. (1997). Property Management: A Customer Focused Approach. Basingstoke: Macmillan.

Eicholtz, P., Kok, N., \& Quigley, J. M. (2010). Doing Well by Doing Good? Green Office Buildings. , 2010a, 100:5, 2492-2509. American Economic Review, 100(5), 2492-2509.

Farncombe, M., \& Waller, A. (2005). Outsourcing for corporate real estate managers: How can real estate learn lessons from other industries? Journal of Corporate Real Estate, $7(3), 258-270$.

Ferreira, J., Pinheiro, M.D., and De Brito, J. (2014). Portuguese sustainable construction assessment tools benchmarked with BREEAM and LEED: An energy analysis. Energy and Building, 69, 451-463.

Feige, A., Wallbaum, H., Janser, M., \& Windlinger, L. (2013). Impact of sustainable office buildings on occupant's comfort and productivity. Journal of Corporate Real Estate, 15(1), 7-34. https://doi.org/10.1108/JCRE-01-2013-0004

Feist, T. (2015). Sustainable Management Matters. Journal of Property Management, 80(3), 12.

Fick, D. (2015). Challenging REIT property management orthodoxy. Retrieved from https://www.cpexecutive.com/media/pdfs/REIT-Whitepaper.pdf

Furst, F., and McAllister, P. (2011). Green noiose or green value? Measuring the effects of environmental certification on office values. Real Estate Economics, 39(1), 45-69.

Gabe, J. (2016). An empirical comparison of voluntary and mandatory building energy performance disclosure outcomes. Energy Policy, 96, 680-687.

Gabe, J., Robinson, S., Sanderford, A., and Simons, R.A. (2019). Lease structures and occupancy costs in eco-labeled buildings. Journal of Property Investment and Finance, 
38(1), 31-46.

Goss, R. C., \& Campbell, H. L. (2008). The Evolution of Residential Property Management: From Caretaker to Income Maximization Managers. Housing and Society, 35(1), 5-20. https://doi.org/10.1080/08882746.2008.11430555

Halvitigala, D., Murphy, L., and Levy, D. (2011). The impact of commercial lease structures on landlord and tenant leasing behaviours and experiences. Pacific Rim Property Research Journal, 17(4), 560-583.

Harris, R. (2019). Real estate in the digital era. Journal of General Management, 44(3), 119127.

Hse, D. (2014). How much information disclosure of building energy performance is necessary? Energy Policy, 64, 263-272.

Hunt, K.G. (2017). Cultivate talent by cultivating culture. Journal of Property Management, 82(4), 8-11.

Hwa, C., Ting, H., Loo, S., Ng, S., \& Memon, M. (2019). Customer orientation and office space performance: Assessing the moderating effect of building grade using PLS-MGA. International Journal of Strategic Property Management, 23(2), 117-129.

Janda, K.B., Bright, S., Patrick, J., Wilkinson, S., and Dixon, T.J. (2016). The evolution of green leases: Towards inter-organizational environmental governance. Building Research and Information, 44(5/6), 660-674.

Jones, C., and Livingstone, N. (2015). Emerging implications of online retailing for real estate: Twenty-first century clicks and bricks. Journal of Corporate Real Estate, 17(3), 226-239.

Kingsley Associates. (2004). Serve and Retain. Journal of Property Management, July/Aug, 
40-43. Retrieved from www.irem.org

Klink, P. (2019). Feel Estate: Delivering Experiential Real Estate Services in the Experience Economy. IREM Journal of Property Management, 84(1), 14-17.

Knapp, C.A., Polucci, T., Sargent, K., and Wright, G. (2019). Rethinking the workplace: How the tech sector influences other industries. Corporate Real Estate Journal, 9(1), $56-70$.

Lecamus, V. (2019). PropTech: What is it and how to address the new wave of real estate startups? Retrieved May 17, 2019, from https://medium.com/@vincentlecamus/proptech-what-is-it-and-how-to-address-the-newwave-of-real-estate-startups-ae9bb52fb128

Levy, D. S., \& Lee, C. K. C. (2009). Switching behaviour in property related professional services. Journal of Property Research, 26(1), 87-103.

Li, J., and Monkkonen, P. (2014). The value of property management services: An experiment. Property Management, 32(3), 213-223.

Lindholm, A.L. (2008), A constructive study on creating core business relevant CREM strategy and performance measures, Facilities, 26(7-8), 343-358.

Londerville, J. (2012). Private sector housing management. North America. International Encyclopedia of Housing and Home (Vol. 5). Elsevier Ltd. https://doi.org/10.1016/B978-0-08-047163-1.00471-9

Lu, S.T., Shiu, J.Y., Chang, D.S. (2014). Development of management support system for property management enterprises. Open Journal of Social Sciences, 2(9), 127-132.

McAllister, P. (2012). Why do research on commercial property management? Somebody HAS to! Property Management, 30(1), 1-6. 
McGrath, K.M. (2013). The effects of eco-certification on office properties: A cap rate-based analysis. Journal of Property Resarch, 30(4), 345-365.

Mclean, A., \& Jegede, T. (2014). The impact of the Energy Act 2011 on loan portfolios. Journal of International Banking Law and Regulation, 29(10), 654-655.

Miller, D. (2001). Survey says: Service = renewals. Journal of Property Management, 66(6), $70-71$.

Miller, N. G., Spivey, J., \& Florance, A. (2008). Does Green Pay Off? Journal of Real Estate Portfolio Management, 14(4), 385-99.

Morgan, H. (2013). At Your Service. RICS Property Journal, (November / December), 2425.

Morgan, H., Middleton, C., Jones, H., \& Sanderson, D. (2019). The Customer Experience Revolution - Closing the Skills Gap. London.

Morgan, H., Purchase, H., Flatto, S., \& Sanderson, D. (2012). Creating Outstanding Customer Experience in Shopping Centres: A Best Practice Guide. London. Retrieved from http://www.bcsc.org.uk/publication.asp?pub_id=463

Morgan, H., \& Sanderson, D. C. (2009). Mall Commercialisation: an introductory guide for retailers and property professionals. London. Retrieved from www.bcsc.org.uk

Morgan, H., Sanderson, D., \& Flatto, S. (2017). Office Service Standards and Customer Experience. London.

MSCI, \& BNP Paribas. (2018). UK Lease Events Review November 2018. London.

Noor, M. N. M., \& Pitt, M. (2009). A discussion of UK commercial property service charges. Journal of Retail and Leisure Property, 8(2), 119-138. 
https://doi.org/10.1057/rlp.2009.4

Noor, M. N. M., Pitt, M., Hunter, G., \& Tucker, M. (2010). Compliance of RICS code of practice for commercial service charges. Journal of Corporate Real Estate, 12(2), 135144.

Ojekalu, S., Ojo, O., Oladokun, T. and Olabisi, S. (2019ạ), Factors influencing service quality: An empirical evidence from property managers of shopping complexes in Ibadan, Nigeria. Property Management, 37(2), 215-228.

Ojekalu, S., Ojo, O., Oladokun, T., Olabisi, S. and Omoniyi, S. (2019흐), Service quality of property managers of shopping complexes in Ibadan, Nigeria: Empirical evidence, Property Management, 37(3), 310-326.

Oyedokun, T., Oletubo, A. and Adewusi, A. (2014). Satisfaction of occupiers with management of rented commercial properties in Nigeria : An empirical study. Property Management, 32(4), 284-294.

Palm, P. (2011). Customer orientation in real-estate companies: The espoused values of customer relations. Property Management, 29(2), 130-145. https://doi.org/10.1108/02637471111122435

Palm, P. (2013). Strategies in Real Estate Management: two strategic pathways. Property Management, 31(4), 311-325.

Palm, P. (2016). Measuring customer satisfaction: A study of the Swedish real estate industry. Property Management, 34(4), 316-331.

Palm, P. (2018). Outsourced property management: The regulation of the property manager. Property Management, 36(5), 620-632.

Phillips, D.R. (2014). Anchoring talent management to businses performance. Journal of 
Property Management, 79(3), 16-20.

Phillips, D.R., \& Roper, K.O. (2009). A framework for talent management in real estate. Journal of Corporate Real Estate, 11(1), 7-16.

https://doi.org/10.1108/14630010910940525

Pinker, S. (2018, February 17). The media exaggerates negative news. This distortion has consequences. The Guardian Newspaper. Retrieved from www.theguardian.com/commentisfree/2018/feb/17/steven-pinker-media-negative-news

Poleg, D. (2020). Rethinking real estate: A roadmap to technology's impact on the world's largest asset class. Cham, Switzerland: Palgrave MacMillan.

Rameezdeen, R., Zuo, J., Ochoa Paniagua, J., Wood, A., and Do, P. (2019). Ensuring environmental performance in green leases: The role of facilities managers. Facilities, 37(9/10), 527-549.

Rameezdeen, R., Zuo, J., and Stevens, J. (2017). Practice, drivers and barriers of implementing green leases: Lessons from South Australia. Journal of Corporate Real Estate, 19(1), 36-52.

Rasila, H. (2010). Customer relationship quality in landlord-tenant relationship. Property Management, 28(2), 80-92.

Read, D.C. (2019). What real estate asset managers do. Institute of Real Estate Management: Chicago, IL.

Read, D. C., \& Carswell, A. (2019). Is property management viewed as a value-added service? Property Management, 37(2), 262-274.

Read, D.C., Hopkins, E., \& Goss, R. C. (2016). Working effectively with asset managers and institutional groups. Property Management, 34(4), 280-296. 
Read, D.C., Hopkins, E., and Goss, R.C. (2017). Strategic business development and client prospecting in the third-party apartment management industry. International Journal of Strategic Property Management, 21(4), 346-356.

Read, D.C., and Sanderford, A. (2017). Innovation districts at the cross roads of the entrepreneurial city and the sustainable city. Journal of Sustainable Real Estate, 9(1), $131-152$.

Read, D.C., and Sanderford, A. (2018). Sustaining sustainability in large real estate investment management firms. Journal of Real Estate Portfolio Management, 24(1), 1933.

RICS. (2009). The Code for Leasing Business Premises in England and Wales 2007. Retrieved from http://www.leasingbusinesspremises.co.uk/downloads/code_comm_lease090805.pdf

RICS. (2011). Commercial property management in England and Wales 2nd Ed. Coventry.

RICS. (2012). Public Sector Property Asset Management Guidelines. London. Retrieved from https://www.rics.org/uk/upholding-professional-standards/sector-standards/realestate/rics-public-sector-property-asset-management-guidelines-2nd-edition/

RICS. (2014). Service charges in commercial property RICS code of practice (Guidance Note) (3rd Editio). London: RICS.

RICS. (2016). Service Charge Residential Management Code, 3rd Edition. London. Retrieved from https://www.rics.org/uk/upholding-professional-standards/sectorstandards/real-estate/service-charge-residential-management-code/

Robinson, S., and McAllister, P. (2015). Heterogeneous price premiums in sustainabl real estate? An investigation of the relation between value and price premiums. Journal of 
Sustainable Real Estate, 7(1), 1-20.

Rosenbaum, M.S., Otalora, M.L., and Ramirez, G.C. (2017). How to create a realistic customer journey map. Business Horizons, 60(1), 143-150.

Sanderson, D. C. (2019). Winning tenants' loyalty in the private rented sector. Property Management, 37(3), 390-417. https://doi.org/10.1108/PM-08-2018-0050

Sanderson, D. C. (2016). The Tenant as Customer: Does Good Service Enhance the Financial Performance of Commercial Real Estate? PhD. Henley Business School, University of Reading.

Sanderson, D.C. (2019). Winning tenants' loyalty in the private rented sector. Property Aangement, 37(3), 390 -417.h\#ps:/ldoi.0rg/10.1108/PM-08 20180050

Sanderson, D. C., \& Devaney, S. (2017). Occupier satisfaction and its impact on investment returns from UK commercial real estate. Journal of Property Investment \& Finance, 35(2), 135-159. https://doi.org/10.1108/JPIF-10-2016-0077

Sanderson, D. C., \& Edwards, V. M. (2016). Determinants of Satisfaction amongst Tenants of UK offices. Journal of Corporate Real Estate, 18(2), 102-131. https://doi.org/10.1108/JCRE-09-2015-0022

Sanquist, N.J. (2013). Embracing the nexus of forcs for increased performance and cost reduction. Corporate Real Estate Journal, 3(4), 307-321.

Sargent, K., Cooper, J., Mellwig, B., and McDonald, M. (2018). Coworking and the disruption of the current corporate real estate model. Corporate Real Estate Journal, 7(3), 267-276. 
Savills. (2019). Savills reveals three quarters of retail landlords are considering repurposing projects. Retrieved September 18, 2019, from https://www.savills.co.uk/insight-andopinion/savills-news/289941/savills-reveals-three-quarters-of-retail-landlords-areconsidering-repurposing-projects

Sayce, S., Sundberg, A., Parnell, P., \& Cowling, E. (2009). Greening Leases: Do tenants in the United Kingdom want Green Leases? Journal of Retail and Leisure Property, 8(4), $273-284$.

Seetharaman, A., Saravanan, A.S., Patwa, N., and Bey, J.M. (2017). the impact of property managemnet services on tenants' satisfcation with industrial buildings. The Journal of Asian Finance, Economics, and Business, 4(3), 57-73.

Sirmans, G. S., \& Sirmans, C. F. (1992). Property Manager Designations and Apartment Rent. Journal of Real Estate Research, 7(1), 91-98.

Taylor, P.C. (2014). Management challenges and responses. Property Management, 32(1), $16-27$.

Thompson, Bob. (2015). Innovation in property management. Journal of Property Investment and Finance, 33(5), 436-445. https://doi.org/10.1108/JPIF-05-2015-0027

Thompson, Brian. (2008). Workplace design and productivity : are they inextricably linked? RICS. London. Retrieved from www.RICS.org

Tucker, M., \& Pitt, M. (2010). Improving service provision through better management and measurement of customer satisfaction in facilities management. Journal of Corporate Real Estate, 12(4), 220-233. https://doi.org/10.1108/14630011011094667

UK Government. Commonhold and Leasehold Reform Act 2002 (2002). UK. Retrieved from https://www.legislation.gov.uk/ukpga/2002/15/contents 
UK Government. (2019). Tenant Fees Act 2019. Retrieved from http://www.legislation.gov.uk/ukpga/2019/4/contents

\section{Wade, J. (2012). Biggest social media risk: Reputation. Risk Management, 59(8), 45}

Wagner, J., \& Watch, D. (2017). Innovation Spaces: The New Design of Work. Washington D.C. Retrieved from https://www.brookings.edu/wpcontent/uploads/2017/04/cs_20170404_innovation_spaces_pdf.pdf

Ward, J. (2018). With industrial space scarce, retailers turn to on-demand warehouses. Retrieved July 19, 2019, from https://therealdeal.com/chicago/2018/12/29/pop-upwarehouses-with-industrial-space-scarce-retailers-turning-to-on-demand-providers/

Westlund, A. H., Gustafsson, C., Lang, E., \& Mattsson, B. (2005). On Customer Satisfaction and Financial Results in the Swedish Real Estate Market. Total Quality Management, 16(10), 1149-1159.

Williford, J. (2005). Customer service legends: Superior service creates stories customers never forget. Journal of Property Management, 70(6), 52.

Wilson, C., Leckman, J., Cappucino, K., \& Pullen, W. (2001). Towards customer delight: Added value in public sector corporate real estate. Journal of Corporate Real Estate, 3(3), 215-221.

World Green Building Council. (2013). The Business Case for Green Building: A Review of the Costs and Benefits for Developers, Investors and Occupants. Retrieved from www.worldgbc.org

Yip, J. (2000). Quality service success - property management development to empowerment: a Hong Kong analysis. Structural Survey, 18(4), 148-154. 
Figure 1. Five Trends Increasing the Importance of Customer-Focused Property Management

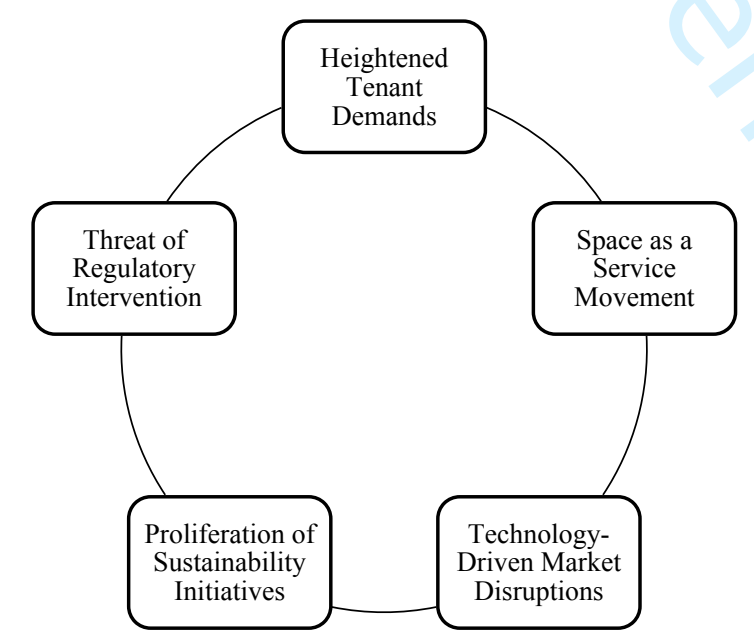


Figure 2. Customer-Focused Property Management Strategies

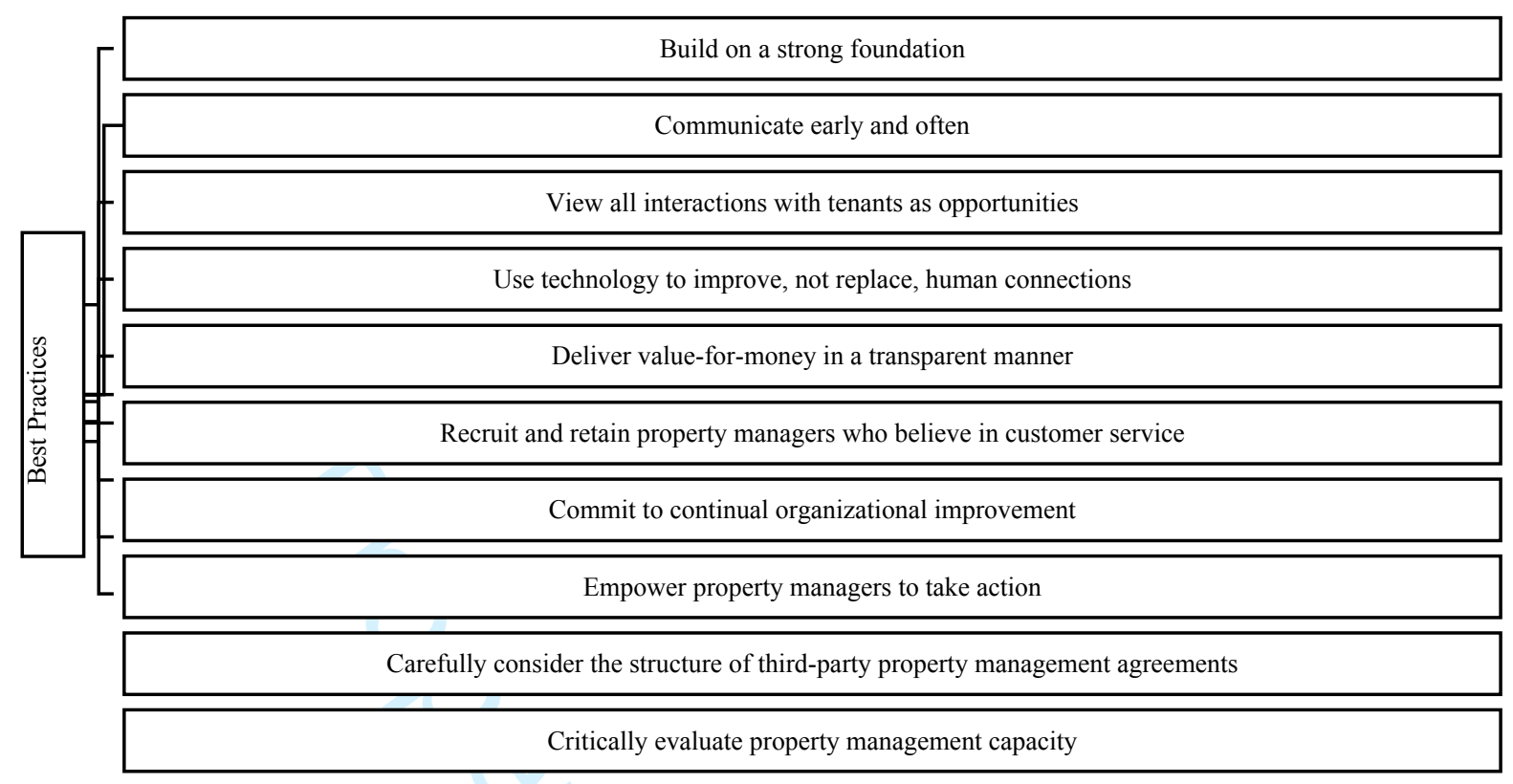

